\title{
Editorial
}

\section{Administrative failure}

Abstract. It is noteworthy how many large, state-sponsored infrastructure projects end in failure. According to H.A. Simon, "administrative man" merely satisfices-chooses a course of action that is "good enough"-in contrast to "economic man", who chooses the best alternative. Administrative man achieves his choice by drastically simplifying his vision of the world, thereby obviating the stupefaction engendered by the richness of the real world's interrelatedness. It is proposed that in our modern, unprecedently complex world, satisficing is no longer adequate and leads to failure. The "Cambridge-Milton Keynes-Oxford Corridor" in the UK is taken as an example. It is further proposed that the work of administrative man could be largely replaced by computer, with only the final choice of action made by man. Finally, it is argued that a "meritocracy", in which high-ranking administrative officials, presently entrusted with guiding large projects, itself leads to mediocrity and failure, because the officials are selected for conformity to social norms and lack the cultural and moral depth required to provide visionary leadership.

Nanotechnology Perceptions 13 (2017) 151-160

doi: 10.4024/N23RA17E.ntp.13.03 